\title{
Lysine Requirement of Laying Hens
}

Teru IsHIBASHI

Faculty of Agriculture, Niigata University, Niigata-shi 950-21

(Received May 1, 1985)

\begin{abstract}
To determine the lysine requirement of laying hens, 3 experiments were conducted. White Leghorn hens older than 12 months were fed diets with graded levels of lysine containing 15\% crude protein and the same essential amino acid pattern except lysine as in whole egg protein for 4 weeks. 2. Egg production rate $\left(Y_{1}, \%\right)$, egg production $\left(Y_{2}, g /\right.$ hen/day) and feed conversion ratio $\left(Y_{3}\right)$ changed curvilinearly according to the following equations: $Y_{1}=-74.4+0.451 X-0.000317 X^{2}, \quad Y_{2}=-15.2+0.190 X-$ $0.000131 X^{2}$ and $Y_{3}=4.75-0.00775 X+0.00544 X^{2}$, where $X$ was $\mathrm{mg}$ of lysine per hen daily. The points where $Y_{1}, Y_{2}$ and $Y_{3}$ reached a maximum or minimum were 711,725 and $712 \mathrm{mg}$ dietary lysine intake/hen/day. 3. Plasma lysine concentrations remained at relatively low levels until dietary lysine intake increased to $667 \mathrm{mg} / \mathrm{hen} /$ day, but thereafter increased rapidly. No effect of dietary lysine was found on the other amino acid concentrations.

Jpn. J. Zootech. Sci., $56(10): 827-834,1985$
\end{abstract}

Key word: Lysine requirement, Laying hen

Since JoHNSON and FISHER ${ }^{1 \text { ) }}$ reported the minimal amino acid requirements of laying hens, many studies on the quantitative requirement of dietary lysine of White Leghorn laying hens for the most effective egg production have been reported ${ }^{2-13)}$. Lysine is essential for laying hens and commonly the first limiting amino acid in commercial diets for laying hens to which a supplement of methionine has been added. Although the $\mathrm{NRC}^{14)}$ recommends a lysine requirement for laying hens of $0.64 \%$ of diet, the values reported from 1962 till today have a wide range from $454^{2)}$ to $920 \mathrm{mg}$ / hen/day ${ }^{12)}$.

The lysine requirement of laying hens is not an absolute figure, but is influenced by several factors such as strain ${ }^{12)}$, body size ${ }^{12)}$, kind of feedstuff ${ }^{8)}$, maximal egg production rate and criteria used for calculating a requirement ${ }^{13)}$. The lysine requirement values mentioned above were mainly estimated from egg production rates, in which the hens were supplied the diets with graded levels of lysine. It has been demonstrated that there is a definite relationship between plasma amino acid levels and the amino acid adequacy of the diet. Plasma lysine concentration remains relatively constant at low levels when the dietary lysine levels are less than the requirement and increases in a linear manner when the dietary lysine levels are moderately in excess of that required to maximize growth of chicks ${ }^{15)}$ and rats $^{16)}$ and to maximize egg production in laying hens ${ }^{13.17}$.

In this paper, we attempted to determine the lysine requirement of laying hens using egg production as the criterion and by the response of plasma lysine concentration to the dietary lysine level. 


\section{Materials and Methods}

Animals. Single Comb White Leghorn hens (Norin 102) older than 12 months and in higher than $80 \%$ egg production were selected and allotted to 5 groups of 5 birds in each experiment. The hens were housed in a single cage in a room with controlled $14 \mathrm{hrs}$ light $(5: 00-19: 00)$ and were fed the diet and water ad libitum. The weight of eggs produced and feed consumption were recorded at 15:00 every day for 32 days in all experiments. Body weight was checked before and after the experiment.

Diets. Corn-based diets were formulated to provide the same amount of essential amino acids except for lysine and tryptophan as in whole egg protein. They furnished crude protein equivalent to $15 \%$ through addition of an amino acid mixture (Table 1). The same amount of trace minerals and vitamins as recommended by the $\mathrm{NRC}^{14)}$ were added to all diets. In experiments 1 and 2, the lysine content was $0.451,0.520,0.590,0.643$ and $0.710 \%$. The tryptophan content was $0.171 \%$ in experiment 1 and $0.230 \%$ in experiment 2, to investigate the effect of dietary tryptophan level on the lysine requirement. To confirm the results obtained in experiments 1 and 2 , in experiment 3 , the hens were given diets with $0.50,0.55,0.60,0.65$ and $0.70 \%$ lysine and $0.171 \%$ tryptophan, respectively. All diets were isocaloric and isonitrogenous. The corn-soybean-based stock diet contained $19.0 \%$ crude protein and $0.71 \%$ lysine.

Plasma amino acid concentrations. After 32 days on experiment about $0.5 \mathrm{ml}$ of blood was taken from the wing vein using heparinized syringes within $1 \mathrm{hr}$ after ovi-

Table 1. Composition of diet $(\mathrm{g} / \mathrm{kg}$ of $\mathrm{diet})$

\begin{tabular}{lccc}
\hline & I & II & II \\
\hline Corn with 2\% fish meal & 750 & 750 & 750 \\
Alfalfa meal & 50 & 50 & 50 \\
Calcium carbonate (oyster shell) & 60 & 60 & 60 \\
Dicalcium phosphate & 20 & 20 & 20 \\
Mineral and vitamin mixture ${ }^{1}$ & 6 & 6 & 6 \\
Corn oil & 30 & 30 & 30 \\
Sodium bicarbonate & 1 & 1 & 1 \\
Agar & 2 & 2 & 2 \\
Amino acid mixture & & 74.36 & 75.05 \\
Tryptophan & 74.29 & 2.30 & 1.71 \\
Lysine & 1.71 & $1.75-4.34$ & $2.24-4.24$ \\
Glutamic acid & $1.75-4.34$ & $2.59-0$ & $2.00-0$ \\
Crude protein (analysis \%) & $2.59-0$ & 15.2 & 15.2 \\
ME (calculation kcal/kg) & 15.1 & 2999 & 2999 \\
\hline
\end{tabular}

1) $6 \mathrm{~g}$ of mixture contained the same amounts of minerals and vitamins as recommended by the $\mathrm{NRC}^{14)}$. 2) Each amino acid was added until the total amino acid levels in the diet were the same as in 150 whole egg protein, as follows: Arg, 8.56; Met, 4.56; Cys, 3.90; Gly, 5.25; Ile, 8.10; Leu, 12.90; Phe, 7.80; Tyr, 7.05; Val, 9.90; His, 2.68; Pro, 6.75 g/kg and Glu, variable. 
position. When the hens did not lay an egg on the next day following blood sampling, blood samplings were repeated again on the following day. Only the blood samples of hens which continued egg production for at least 2 consecutive days were used for the determination of amino acids with an automatic amino acid analyzer (Nihon Denshi, JIC-6 AH). Plasma was separated by centrifugation after adding the same volumes of $3 \%$ sulfosalicylic acid and stored at $-20^{\circ} \mathrm{C}$ until further analysis.

Statistical method. The significance of differences among treatment means was determined by Duncan's multiple range test according to the methods described by YoshIDA ${ }^{18)}$.

\section{Results}

Egg production rates. Since the effect of prefeeding diets on the egg production rate lasted for about 4 days, data were gathered for 4 weeks from the 5 th to the 32nd day after switching from the stock diet to the experimental diets. As shown in Table 2, the egg production rate increased with increasing dietary lysine intake, reached a maximum level on a $711 \mathrm{mg}$ lysine intake and then decreased. The polynominal equation computed by the method of linear squares was $Y_{1}=-74.4+0.451 X-$

Table 2. Effects of dietary lysine intake on productivity of laying hens

\begin{tabular}{|c|c|c|c|c|c|c|c|}
\hline $\begin{array}{l}\text { Trp } \\
(\%)\end{array}$ & $\begin{array}{l}\text { Lys } \\
(\%)\end{array}$ & $\begin{array}{l}\text { Food intake } \\
\text { (g/hen/day) }\end{array}$ & $\begin{array}{l}\text { Lysine intake } \\
\text { (mg/hen/day) }\end{array}$ & \multicolumn{2}{|c|}{$\begin{array}{l}\text { Egg production } \\
1 \% \text { before } 4 \mathrm{~W}\end{array}$} & \multirow[t]{2}{*}{$\begin{array}{l}\text { Egg production } \\
(\mathrm{g} / \text { hen/day })\end{array}$} & \multirow[t]{2}{*}{$\begin{array}{l}\text { Feed } \\
\text { conversion } \\
\text { ratio }\end{array}$} \\
\hline \multicolumn{6}{|c|}{ Experiment 1} & & \\
\hline \multirow[t]{5}{*}{0.171} & 0.451 & 106.2 & $479^{a}$ & 94.3 & $71.4^{\mathrm{a}}$ & $49.9^{3}$ & $2.26^{\mathrm{a}}$ \\
\hline & 0.520 & 105.8 & $550^{b}$ & 94.3 & $82.1^{\mathrm{b}}$ & $50.6^{\mathrm{ab}}$ & 2. $09^{a b}$ \\
\hline & 0.590 & 108.4 & $640^{c}$ & 91.4 & $88.6^{b}$ & $55.6^{\mathrm{b}}$ & $1.95^{b}$ \\
\hline & 0.643 & 106.3 & $684^{\mathrm{d}}$ & 91.4 & $87.1^{b}$ & $55.1^{b}$ & $1.93^{\mathrm{b}}$ \\
\hline & 0.710 & 107.2 & $761^{e}$ & 91.4 & $86.4^{b}$ & $53.6^{b}$ & 2. $00^{\mathrm{ab}}$ \\
\hline \multicolumn{2}{|c|}{ Pooled SE } & 1.2 & 4 & 3.6 & 3. 2 & 2.0 & 0.08 \\
\hline \multicolumn{8}{|c|}{ Experiment 2} \\
\hline \multirow[t]{4}{*}{0.230} & 0.451 & $100.7^{3}$ & $454^{\mathrm{a}}$ & 91.4 & $66.4^{\mathrm{a}}$ & 43. $7^{\mathrm{a}}$ & 2. $30^{\mathrm{a}}$ \\
\hline & 0.520 & $108.1^{b}$ & $562^{b}$ & 94.3 & $78.5^{b}$ & 49. $3^{\mathrm{b}}$ & 2. $19^{\mathrm{ab}}$ \\
\hline & 0.590 & $105.9^{b}$ & $625^{c}$ & 91.4 & $83.6^{b}$ & $51.5^{\mathrm{b}}$ & $2.06^{b}$ \\
\hline & 0. 643 & $107.7^{b}$ & $693^{d}$ & 94.3 & $87.1^{b}$ & $53.3^{b}$ & $2.02^{\mathrm{b}}$ \\
\hline & 0.710 & 108. $4^{b}$ & $770^{e}$ & 94.3 & $84.8^{b}$ & $52.5^{b}$ & $2.06^{\mathrm{b}}$ \\
\hline \multicolumn{2}{|c|}{ Pooled SE } & 1.1 & 5 & 3.6 & 2. 9 & 1.4 & 0.07 \\
\hline \multicolumn{8}{|c|}{ Experiment 3} \\
\hline \multirow[t]{5}{*}{0.171} & 0.495 & $104.8^{\text {ab }}$ & $519^{a}$ & 94.3 & $68.6^{\mathrm{a}}$ & $45.3^{4}$ & $2.31^{x}$ \\
\hline & 0.547 & $103.0^{a}$ & $564^{b}$ & 91.4 & $76.4^{\mathrm{ab}}$ & 48. $0^{\mathrm{ab}}$ & $2.15^{\mathrm{ab}}$ \\
\hline & 0.594 & 108.9 & $644^{c}$ & 91.4 & $83.6^{b}$ & $54.0^{b}$ & $2.02^{\mathrm{ab}}$ \\
\hline & 0.643 & $107.1^{b c}$ & $689^{d}$ & 94.3 & $85.0^{\circ}$ & $55.1^{\mathrm{b}}$ & $1.94^{b}$ \\
\hline & 0.691 & $109.6^{c}$ & $757^{\mathrm{e}}$ & 94.3 & $83.6^{b}$ & $54.3^{b}$ & 2. $02^{\mathrm{ab}}$ \\
\hline \multicolumn{2}{|c|}{ Pooled SE } & 1.0 & 4 & 3.6 & 3.0 & 2.3 & 0.10 \\
\hline
\end{tabular}

Means for 5 hens each. Values in the same column with different superscript letters differ significantly at the $5 \%$ level. 


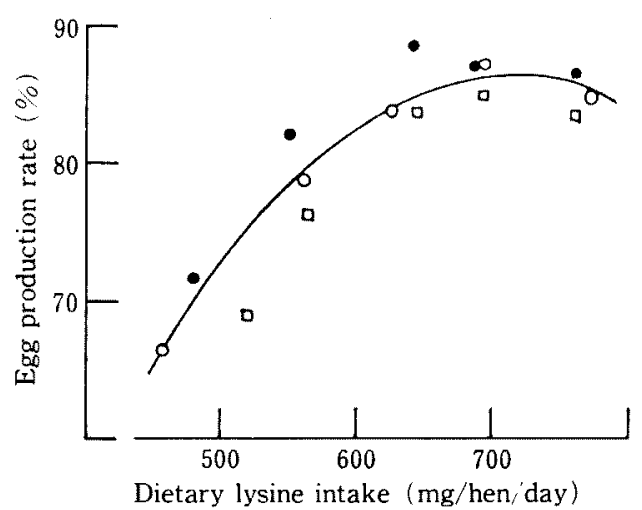

Fig. 1. Effects of dietary lysine intake on egg production rate in experiment 1 (๑), 2 (O) and $3(\square)$.

$0.000317 X^{2} \quad(r=0.899)$, where $Y_{1}$ and $X$ represent percentage of egg production and mg of lysine per hen daily. The curvilinear response curve based on this equation and a plot of the data observed against the dietary lysine intake are shown in Fig. 1. The point at which egg production rate maximized $(86.4 \%)$ on the basis of the regression equation corresponded to a daily intake of $711 \mathrm{mg}$ lysine per hen.

Egg production. Since the weight of each egg changed within a narrow range during the experimental periods, a similar polynomial equation was fit to the egg production data. The polynomial equation for egg weight was $Y_{2}=-15.2+0.190 X-$ $0.000131 X^{2}(\mathrm{r}=0.930)$. This regression equation showed that maximum egg production $(53.8 \mathrm{~g}$ ) was obtained with an intake of $725 \mathrm{mg}$ lysine per hen daily. This estimation was $2 \%$ higher than that by egg production rate.

Feed intake. When the dietary lysine levels were lower than $0.547 \%$, feed intake decreased, but no dose-related response was found at higher dietary lysine levels.

Feed conversion ratio. The response of feed conversion ratio was influenced by different dietary lysine intakes with a curvilinear equation, $Y_{3}=4.75-0.00775 X+$ $0.00544 X^{2} \quad(r=0.950)$. The minimal feed conversion ratio was attained at $712 \mathrm{mg}$ lysine intake, which agreed very well with that of egg production rate.

Body weight. The initial body weight of laying hens was $1656 \pm 22,1649 \pm 33$ and $1677 \pm 32$ in experiments 1,2 and 3 , respectively. Since no significant changes were observed during the experimental periods, the data are not presented here. No abnormality was found in any birds except 1 and 2 hens on the $0.415 \%$ lysine diet in experiments 1 and 2, respectively, molted lightly during the 4th week.

Plasma amino acid concentration. The results for plasma concentrations of tryptophan, lysine, arginine and phenylalanine are shown in Table 3. The concentrations of other amino acids measured are not presented here, since they were not affected by the dietary lysine intakes as were arginine and phenylalanine. The plasma tryptophan concentration remained constant at all dietary lysine intake levels at both dietary tryptophan levels. But lysine concentrations on the $0.171 \%$ tryptophan diet 


\section{Lysine Requirement of Laying Hens}

Table 3. Effects of dietary lysine levels on plasma amino acid concentrations

\begin{tabular}{|c|c|c|c|c|c|}
\hline \multirow{2}{*}{\multicolumn{2}{|c|}{$\underset{(\% \text { of diet })}{\text { Lys }}$}} & \multicolumn{4}{|c|}{ Plasma amino acids $(\mathrm{nmol} / \mathrm{m} l)$} \\
\hline & & $\operatorname{Trp}$ & Lys & $\operatorname{Arg}$ & Phe \\
\hline \multicolumn{6}{|c|}{ Experiment 1} \\
\hline \multirow[t]{6}{*}{0.171} & $0.45 !$ & 50 & $195^{\mathrm{a}}$ & 244 & 91 \\
\hline & 0.520 & 54 & $207^{\mathrm{a}}$ & 272 & 88 \\
\hline & 0.590 & 50 & $218^{2}$ & 244 & 74 \\
\hline & 0.643 & 60 & $274^{b}$ & 290 & 95 \\
\hline & 0.710 & 52 & $421^{\mathrm{c}}$ & 252 & 94 \\
\hline & ed SE & 5 & 10 & 11 & 5 \\
\hline \multicolumn{6}{|c|}{ Experiment 2} \\
\hline \multirow[t]{6}{*}{0.230} & 0.451 & 64 & $161^{\mathrm{a}}$ & 258 & 99 \\
\hline & 0.521 & 59 & $178^{\mathrm{a}}$ & 239 & 86 \\
\hline & 0.590 & 57 & $188^{a}$ & 269 & 80 \\
\hline & 0.643 & 56 & $245^{b}$ & 241 & 98 \\
\hline & 0.710 & 59 & $405^{c}$ & 252 & 103 \\
\hline & ed SE & 3 & 9 & 13 & 4 \\
\hline \multicolumn{6}{|c|}{ Experimenr 3} \\
\hline \multirow[t]{6}{*}{0.171} & 0.495 & 50 & $180^{\mathrm{a}}$ & 260 & 98 \\
\hline & 0.547 & 58 & $196^{2}$ & 237 & 97 \\
\hline & 0.594 & 47 & $204^{a}$ & 282 & 105 \\
\hline & 0.643 & 56 & $248^{b}$ & 292 & 102 \\
\hline & 0.691 & 58 & $437^{c}$ & 254 & 103 \\
\hline & ed $\mathrm{SE}$ & 3 & 10 & 11 & 3 \\
\hline
\end{tabular}

See footnotes in Table 1.

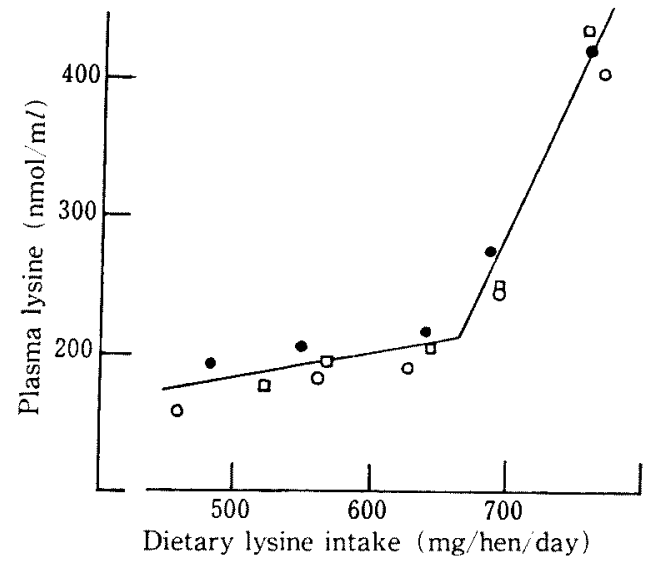

Fig. 2. Effects of dietary lysine intake on plasma lysine concentrations in experiment $1(\bullet), 2(0)$ and $3(\square)$.

(experiments 1 and 2) were always higher than those on the $0.230 \%$ tryptophan diet (experiment 2).

As shown in Fig. 2, the plasma lysine concentration increased very slowly up to 
a $667 \mathrm{mg}$ lysine intake per hen daily $\left(Y_{4}=0.17 X+99, \mathrm{r}=0.657\right)$. Above that level, the plasma lysine concentration increased rapidly according to the equation, $Y_{5}=$ 2. $16 \mathrm{X}-1228 \quad(\mathrm{r}=0.962)$, where $Y$ and $X$ represent $\mathrm{nmol} / \mathrm{ml}$ of lysine and $\mathrm{mg}$ of dietary lysine intake, respectively. The requirement point from both equations was estimated to be $667 \mathrm{mg} /$ hen daily. This value was $6 \%$ less than that estimated from the maximum egg production rate.

\section{Discussion}

The requirement of lysine for maximal productivity obtained from egg production rate, egg production, feed conversion ratio and plasma lysine response were 711,725 , 712 and $667 \mathrm{mg} /$ hen daily. These values were higher than those of Moran et al. ${ }^{2}$ (454), Harm and Waldroup ${ }^{3)}$ (494), BraY ${ }^{4}$ ) (520), LAStshaw ${ }^{5)}$ (585-650), Sell and HodgSon $^{\text {7) }}$ (620-660) and Shell and JoHnSoN ${ }^{8)}$ (625), but agree with those of HURwitz and BoRNSTEIN ${ }^{6)}$ (627-836) and JENSEN et al." ${ }^{11)}$ (666-788). Higher dietary lysine requirements have been reported for wheat-based rations. MARCH and BIELY ${ }^{10)}$ stated that hens fed wheat-based rations required 800 to $850 \mathrm{mg}$ of lysine daily. Similarly, Jensen et al. ${ }^{11}$ and Pilbrow and Morris ${ }^{12)}$ reported that 765 to $900 \mathrm{mg}$ lysine per hen daily were needed to support maximum egg production. On the other hand, SHELL and HodGsoN ${ }^{7)}$ and Shell and JoHnsoN ${ }^{8)}$ found that 620 to $660 \mathrm{mg}$ lysine from wheatbased diets satisfied the daily requirement of hens. These differences might be partly due to differences in availability of lysine in feedstuffs, because the availability of corn is higher $(85-90 \%)$ than that of wheat $(75 \%)$ (YAMAZAKI, unpublished data).

In the $0.643 \%$ lysine diet, $0.176,0.063,0.037$ and $0.367 \%$ of lysine were derived respectively from corn, fish meal, alfalfa and crystalline lysine. Assuming an availability of lysine in corn is $86 \%^{19)}$ and $85 \%$ in fish meal and alfalfa and $100 \%$ in crystalline lysine, the availability of lysine of this diet might not be less than $94 \%$. Since the maximum $53.8 \mathrm{~g}$ of egg was obtained at a $725 \mathrm{mg}$ dietary lysine intake, and since $426 \mathrm{mg}$ lysine was present in $53.8 \mathrm{~g} \mathrm{egg}$, the availability of absorbed lysine for egg formation would be estimated to be $63.9 \%(426 / 725 \times 0.92)$. Since hens used for maintenance $66 \mathrm{mg}$ lysine $/$ hen daily $\left(40 \mathrm{mg} / \mathrm{kg} /\right.$ day for maintenance $\left.\mathrm{e}^{20}\right) \times 1.66 \mathrm{~kg}$ average body weight in experiments 1 to 3 ), the true availability of absorbed lysine might be estimated to be $75.0 \%((426+66) / 713 \times 0.92)$.

As the hens on 0.590 and $0.643 \%$ lysine diets consumed $107.4 \mathrm{~g} / \mathrm{day}$, the diet for maximal egg production rate should contain approximately $0.66 \%$ of lysine $(711$ $\mathrm{mg} / 107.4 \mathrm{~g}$ ), if the availability of lysine in feedstuffs was the same as in this experiment diet, which was $3 \%$ higher than the $\mathrm{NRC}^{14)}$ recommendation.

The response of plasma lysine concentration could be used to estimate the dietary requirement of lysine for laying hens as in chicks ${ }^{15)}$ and rats ${ }^{13-17)}$. As CHI and SPEERS 13.17) reported, when hens were fed a diet containing varying amounts of lysine, plasma lysine remained at relatively low levels until dietary lysine intake increased to 667 $\mathrm{mg} /$ hen/day, but thereafter increased rapidly. In contrast to the observations by $\mathrm{CHI}$ and SPEERS ${ }^{17}$, no significant response to the dietary lysine intake was found for other 


\section{Lysine Requirement of Laying Hens}

amino acids. The decrease in the plasma arginine level with an increase of dietary lysine has been shown in chicks ${ }^{21-22}$ ) and laying hens ${ }^{19)}$. However, as shown in Table 3, the plasma arginine concentration was not changed with a trend corresponding to the dietary intake levels. The plasma arginine concentration was reduced only in hens fed a diet containing $0.85 \%$ lysine, suggesting that the lysine levels employed here were too low to induce the lysine-arginine antagonistic relationship in laying hens.

\section{Acknowledgements}

The author is grateful to Dr. H. FISHER, of Rutgers University, for his reading of the manuscript and to Kyowa Hakko Kogyo Co., Ltd. and Takeda Feed Supplement Co., Ltd. for generously supplying crystalline amino acids and vitamin-mineral premix.

\section{References}

1) Johnson, D. Jr. and H. Fisher, Brit. J. Nutr., 12: 276-285. 1958.

2) Moran, E. T., J. D. Summers and W. F. Pepper, Poult. Sci., 46: 1134-1144. 1967.

3) Harms, R. H. and P. W. Waldroup, Brit. Poult. Sci., 3: 267-273. 1962.

4) Bray, D. T., Poult. Sci., 48: 674-684. 1969.

5) Lastshaw, J. D., Poult. Sci., 55: 2348-2353. 1976.

6) Hurwitz, S. and S. Bornstein, Poult. Sci., 56: 969-978. 1977.

7) Shell, J. L. and G. C. Hodeson, Poult. Sci., 45: 247-253. 1966.

8) Shell, J. L. and L. Johnson, Brit. Poult. Sci., 15: 43-49. 1974.

9) Nathanafl, A. S. and J. L. Shell, Poult. Sci, 59: 594-597, 1980.

10) March, B.E. and J. Biely, Poult. Sci., 51: 547-557. 1972.

11) Jensen, L. S., S. H. Chang and L. Falen, Poult. Sci., 53: 1387-1391. 1974.

12) Pilbrow, P. Y. and T.R. Morris, Brit. Poult. Sci., 15: 51-73. 1974.

13) CHI, Y.S. and G. M. SPEERS, J. Nutr., 106: 1192-1201. 1976.

14) NRC, Nutrient requirements of poultry, 8th rev. ed. Natl. Acad. Sci., Washington, D. C. 1984.

15) Zimmerman, R. A. and H. M. Scott, J. Nutr., 87: 13-18. 1965.

16) Stockland, W. L., R. J. Helliere, J. Nutr, 100: 925-934. 1970.

17) Chi, Y.S. and G. M. Speers, Poult. Sci, 56: 521-528. 1977.

18) Yoshida, M. in Design of experiments for animal husbandry (Jpn) 85 Yokendo. Tokyo. 1980.

19) YамаzaKı, M., Jpn. Zootech. Sci., 54: 729-733. 1983.

20) Ishibashi, T., Jpn. Zootech. Sci, 44: 39-49. 1973.

21) Jones, J. D., J. Nutr., 84: 313-321. 1964.

22) Jones, J. D., S. J. Petersburg and P. C. Burnet, J. Nutr., 93: 103-110. 1967. 


\section{産卵鶏のリジン要求量}

\section{石 橋 晃}

新潟大学塬学部, 新潟市 950-21

1. 産畉謟のリジン要求量を求めるだめ，12 力月䊀以 上の産卵熖老用いて，3試䮖を行なった。・ウモロコシ 主体の飼料にりジンとトリブトフォン以外は15\%全卵 㔻白質と同しになるよらに結晶てミ，酸混合物を添加し to.

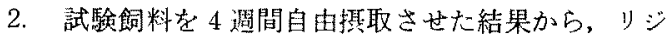
ン摄取量 $(X, \mathrm{mg} /$ 羽/日) に対し，

産䀦率 $Y_{1}(\%)=-74.4+0.451 X-0.000317 X^{2}$

産卵重量 $Y_{2}(\mathrm{~g} /$ 羽/日 $)=-15.2+0.190 X-0.000$
$131 X^{2}$

飼料要求率 $Y_{3}=4.75-0.00775 X+0.00544 X^{2}$ といら回㷌式が得られた。それぞれの式から，要求量は $711 ， 725 ， 712 \mathrm{mg} /$ 羽/日上計算された。

3. 血槳中のリジン濃度は $667 \mathrm{mg} /$ 羽/日まではゆっ くり增加し，穴の後は急に增加した。ここで用いた飼料 中のリジン量では他のアミノ酸の血獎中の濃度に影響は みられながだ。

日畜会報，56(10)：827-834，1985 